\title{
Determining the Competencies Necessary for Exporting in Furniture Industry with Decision Tree Models
}

\section{Određivanje izvoznih kompetencija u industriji namještaja uz pomoć modela stabla odlučivanja}

\author{
Original scientific paper • Izvorni znanstveni rad \\ Received-prispjelo: 13. 11. 2019. \\ Accepted-prihvaćeno: 14. 1. 2021. \\ UDK: $630 * 7$ \\ https://doi.org/10.5552/drvind.2021.1952
}

(C) 2021 by the author(s). Licensee Faculty of Forestry, University of Zagreb. This article is an open access article distributed under the terms and conditions of the Creative Commons Attribution (CC BY 4.0) license.

\begin{abstract}
In order to increase the competitiveness of companies, there are factors that need to be considered both in the domestic and foreign markets. In particular, companies that want to maintain their presence in the foreign market must differentiate from other companies in the industry and gain significant advantages over their competitors in order to maintain this continuity. If companies pay more attention to the factors that are effective in export, they can be predicted to be successful in competition and especially in export. The aim of this study was to determine the factors and issues affecting export performance in furniture industry and to determine the effect of these factors and issues on exports. In this context, the application data were obtained from the survey of 182 managers of companies operating in the furniture industry in Turkey. The scenarios produced in the study were made with J48 algorithm-decision trees modeling, which is one of the data mining methods. Thanks to these scenarios, road maps were drawn to give ideas to the companies and managers planning to export. As a result of this study, the "staff status" factor, the "manager's overseas experience" and "the legal form of the company" were identified as the main determinants of export.
\end{abstract}

Keywords: export determinants; furniture industry; data mining; decision trees

SAŽETAK • Kako bi se povećala konkurentnost tvrtke, potrebno je uzeti u obzir čimbenike koji utječu na domaće $i$ inozemno tržište. Tvrtke koje žele biti kontinuirano zastupljene na inozemnom tržištu moraju se izdvajati od ostalih tvrtki i imati znatne prednosti pred konkurentskim tvrtkama. Ako tvrtke više pozornosti pridaju čimbenicima koji utječu na izvoz, može se očekivati da će biti konkurentne u izvozu svojih proizvoda. Cilj ovog istraživanja bio je utvrditi čimbenike i probleme koji u industriji namještaja utječu na izvoz i procijeniti njihov utjecaj na izvoznu uspješnost. U tu su svrhu anketirana 182 voditelja tvrtki za proizvodnju namještaja koje posluju u Turskoj. Scenariji prikazani u ovom istraživanju načinjeni su uz pomoću algoritma J48 - modela stabla odlučivanja, što je jedna od metoda rudarenja podataka. Zahvaljujući tim scenarijima, izrađeni su hodogrami koji mogu pomoći tvrtkama $i$ voditeljima u planiranju izvoza. Rezultati ovog istraživanja pokazali su da su glavne odrednice izvoza status osoblja, inozemno iskustvo voditelja tvrtke i pravni oblik tvrtke.

Ključne riječi: odrednice izvoza; industrija namještaja; rudarenje podataka; stablo odlučivanja

\footnotetext{
${ }^{1}$ Author is researcher at Bartin University, Faculty of Economics and Administrative Sciences, Department of Management Information Systems, Bartin, Turkey.

${ }^{2}$ Author is researcher at Zonguldak Bülent Ecevit University, Faculty of Economics and Administrative Sciences, Department of Business Administration, Zonguldak, Turkey.
} 


\section{INTRODUCTION}

\section{UVOD}

Furniture industry is an important foreign trade area in the world. The furniture industry is an important economic factor in the world with its rapidly increasing growth and an annual value of approximately 437 billion dollars. In the furniture industry, which was once dominated by European countries, China has been the leading world industry with a $35 \%$ share in recent years. Although Asia and the Pacific continue to be the fastest growing regions, it is noteworthy that in 2016 China's exports in furniture decreased, while Vietnam became the fastest growing furniture industry. In the last 5 years, the increase in furniture imports in the USA increased from 23 billion dollars to 32 billion dollars and became the main source of growth in this industry (TRADEMAP, 2019). Figure 1 presents the leading exporters in the furniture industry in the world.

In terms of exports, being successful in world trade is possible by following a competitive policy at a global level. In this case, it is possible to measure the foreign trade ability of a country and an industry by determining the factors affecting the export performance.

It has been observed that scientific studies related to export performance are mostly conducted in nonfurniture industries. In the scientific studies related to the furniture industry, subjects other than export performance have been addressed. In this context, this study is original.

The motivations of this paper can be listed as follows: (1) no academic studies observed the determinants of exporting performance of companies on the world furniture market, which is fast growing based on decision tree approach; (2) almost no assumptions are needed in decision tree modelling such as in regression models; (3) the question whether there are any different determinants in furniture export industry with respect to other industries and other countries. Accordingly, researching these items can be considered as highlights of the study.
In the literature on export performance, the following models were widely used: Export Performance and Determinant Model (Aaby and Slater, 1989), Export Performance Model (Dhanaraj and Beamish, 2003), Determining Models of Export Performance (Madsen, 1989), Theoretical Model (Gemunden, 1991) and Export Performance Model (Zou and Stan, 1998). In addition, in many studies, it can be found that the factors affecting export performance are divided into two groups, both internal and external factors, and economic and non-economic factors.

When the literature is examined in detail, it can be observed that many researchers divide the variables used into internal and external variables. Internal variables used in scientific studies are divided into titles as management characteristics and perceptions, organizational capabilities, knowledge-based factors, relational factors and company characteristics. The variables under these main headings and the researchers using these variables are given in Table 1 .

The external variables used in the measurement of export performance in the literature are given under two main headings: domestic market characteristics and characteristics of export market. The external variables used under these main headings are given in Table 2 .

On the other hand, many scientists working on export performance categorized the factors that are effective in performance measurement in two sub-headings as economic factors and non-economic factors. The factors that are economic are related to sales and market relations (Table 3 ).

Non-economic factors are evaluated under two headings as "General" and "Other". These factors and the studies using these factors are given in Table 4.

\section{MATERIALS AND METHODS} 2. MATERIJALI I METODE

In the questionnaire prepared to be used in the analysis of the study, opinions about the characteris-

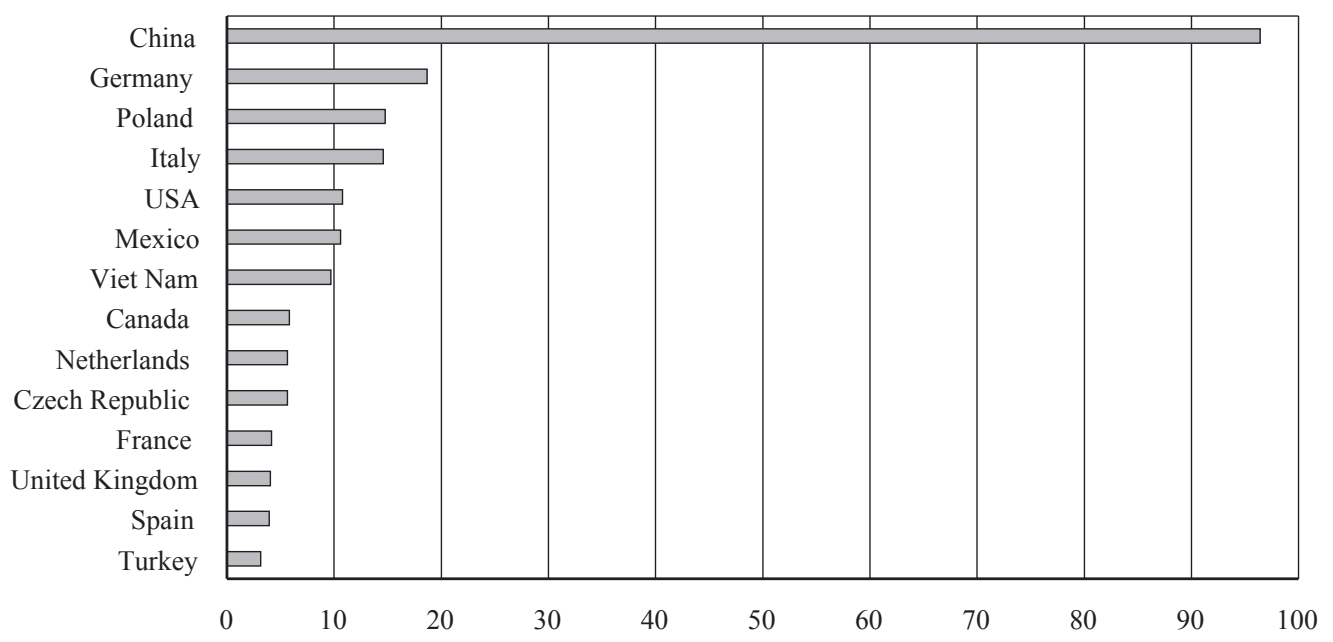

Figure 1 Exports in wood furniture of major countries in world furniture exports in 2018, in billion \$ (TRADEMAP, 2019) Slika 1. Izvoz drvenog namještaja vodećih zemalja u izvozu namještaja u svijetu u 2018. (u mlrd. USD) (TRADEMAP, 2019.) 
.... Aytekin, Pekkaya: Determining the Competencies Necessary for Exporting in Furniture...

Table 1 Internal variables used in measurement of export performance

Tablica 1. Unutarnje varijable upotrijebljene u procjeni odrednica izvoza

\begin{tabular}{|c|c|}
\hline Internal variables / Unutarnje varijable & References / Literatura \\
\hline $\begin{array}{l}\text { Management features and perceptions / Značajke } i \\
\text { percepcije upravljanja } \\
\text { Export commitment and support / izvozna predanost } i \\
\text { potpora } \\
\text { International experience / međunarodno iskustvo } \\
\text { International orientation / međunarodna orijentacija } \\
\text { Export motivation / motivacija za izvoz } \\
\text { Perception of export advantages / percepcija prednosti } \\
\text { izvoza } \\
\text { Age, Education / dob, obrazovanje }\end{array}$ & $\begin{array}{l}\text { Reid, 1983; Çavuşgil, 1984; Aaby and Slater, 1989; Rocha et al., } \\
\text { 1990; Dichtl, Koeglmayr and Müller, 1990; Holzmüller and Stöt- } \\
\text { tinger, 1996; Czinkota and Ursic, 1991; Oviatt and McDougall, } \\
\text { 1994; Çavuşgil and Zou, 1994; Roth, 1995; White } \text { et al., 1998; Zou } \\
\text { and Stan, 1998; Beamish et al., 1999; Jones, 2001; Styles and Am- } \\
\text { bler, 2000; Dean et al., 2000; Katsikeas et al., 2006; Stöttinger and } \\
\text { Holzmüller, 2001; Gençtürk and Kotabe, 2001; Ibeh and Young, } \\
\text { 2001; O'Cass and Julian, 2003; Ibeh, 2003; Alvarez, 2002; Con- } \\
\text { tractor et al., 2003; Lages and Montgomery, 2004; Ibeh and Wheel- } \\
\text { er, 2005; Brouthers and Nakos, 2005; Cadogan et al., 2005; Lejpras, } \\
2019\end{array}$ \\
\hline $\begin{array}{l}\text { Organization capabilities / Mogućnosti organizacije } \\
\text { Advanced technology / napredna tehnologija } \\
\text { Product - service quality / kvaliteta proizvoda/usluge }\end{array}$ & $\begin{array}{l}\text { Madsen 1989; Çavuşgil et al., 1993; Chetty and Hamilton, 1993; } \\
\text { Styles and Ambler, 1994; Thirkell and Dau, 1998; Piercy et al., } \\
\text { 1998; Robertson and Chetty, 2000; Prasad et al., 2001; Shoham et } \\
\text { al., 2002; Balabanis and Katsikea, 2003; O'Cass and Julian, 2003; } \\
\text { Yeoh, 2004; Alvarez, 2004; Contractor et al., 2003; Haahti et al., } \\
\text { 2005; Lopez-Rodriguez and Rodriguez, 2005; Lejpras, } 2019\end{array}$ \\
\hline $\begin{array}{l}\text { Export strategy / strategija izvoza } \\
\text { Export planning / planiranje izvoza } \\
\text { Export organization / organizacija izvoza } \\
\text { Market expansion / širenje tržišta } \\
\text { Service strategy / strategija usluge } \\
\text { Risk taking, Control, Process / preuzimanje rizika, } \\
\text { kontrola, postupak }\end{array}$ & $\begin{array}{l}\text { White et al., 1998; Hoang, 1998; Zou and Stan, 1998; Piercy et al., } \\
\text { 1998; Aaby and Slater, 1989; Shoham, 1999a; Robertson and Chet- } \\
\text { ty, 2000; Baldauf et al., 2000; Dean et al., 2000; Francis and Col- } \\
\text { lins-Dodd, 2004; Li and Ogunmokun, 2001; Shoham et al., 2002; } \\
\text { Solberg, 2002; Balabanis and Katsikea, 2003; Deng et al., 2002; } \\
\text { Dhanaraj and Beamish, 2003; Julien and Ramangalahy, 2008; } \\
\text { Chung, 2003; Chen et al., 2004; Li, 2004; Haahti et al., 2005; Ibeh } \\
\text { and Wheeler, 2005; Brouthers and Nakos, 2005; Contractor et al., } \\
2003\end{array}$ \\
\hline $\begin{array}{l}\text { Marketing Mix / marketinški miks } \\
\text { Product strategy / strategija proizvoda } \\
\text { Price strategy / strategija cijena } \\
\text { Promotional strategy / promidžbena strategija } \\
\text { Distribution strategy / strategija distribucije }\end{array}$ & $\begin{array}{l}\text { Amine and Çavuşgil, 1986; Madsen, 1989; Fraser and Hite, 1990; } \\
\text { Louter et al., 1991; Dominguez and Sequeira, 1993; Beamish et al., } \\
\text { 1993; Styles and Ambler, 1994; Çavuşgil and Zou, 1994; Thirkell } \\
\text { and Dau, 1998; Piercy et al., 1998; Hoang, 1998; Samiee and An- } \\
\text { ckar, 1998; Shoham, 1999b; Myers, 1999; Robertson and Chetty, } \\
\text { 2000; Gençtürk and Kotabe, 2001; Albaum and Tse, 2001; Li and } \\
\text { Ogunmokun, 2001; Brouthers and Xu, 2002; Shoham et al., 2002; } \\
\text { Chung, 2003; O'Cass and Julian, 2003; Morgan et al., 2004; Lee } \\
\text { and Griffith, 2004; Chen et al., 2004; Lages and Montgomery, } \\
\text { 2004; Brouthers and Nakos, } 2005\end{array}$ \\
\hline $\begin{array}{l}\text { Knowledge-based factors / Čimbenici utemeljeni na } \\
\text { znanju } \\
\text { Export expertise / izvozna ekspertiza } \\
\text { International experience / međunarodno iskustvo }\end{array}$ & $\begin{array}{l}\text { Hoang, 1998; Baldauf et al., 2000; Dean et al., 2000; Francis and } \\
\text { Collins-Dodd, 2004; Li, 2004; Li and Ogunmokun, 2001; Prasad et } \\
\text { al., 2001; Brouthers and Xu, 2002; Solberg, 2002; Deng et al., } \\
\text { 2002; O'Cass and Julian, 2003; Chen et al., 2004; Contractor et al., } \\
\text { 2003; Brouthers and Nakos, 2005; Lejpras, 2019 }\end{array}$ \\
\hline $\begin{array}{l}\text { Export information, Market research, Customer } \\
\text { information, Market information, Competitor informa- } \\
\text { tion, Supply chain channel information } \\
\text { informacije o izvozu, istraživanje tržišta; podatci o } \\
\text { kupcima; podatci o tržištu; podatci o konkurentima; } \\
\text { podatci o kanalu lanca opskrbe }\end{array}$ & $\begin{array}{l}\text { Kogut and Zander, 1992; Grant, 1996; Teece et al., 1997; Hart and } \\
\text { Tzokas, 1999; Yeoh, 2004; Richey and Myers, 2001; Solberg, 2002; } \\
\text { Morgan et al., 2003; Li, } 2004\end{array}$ \\
\hline $\begin{array}{l}\text { Business and corporate relations, Distribution channel } \\
\text { relationship, Customer relationship, Supplier relation- } \\
\text { ship, Partnership relationship, Membership in regis- } \\
\text { tered and unregistered commercial networks, Govern- } \\
\text { ment and other corporate relations } \\
\text { poslovni i korporativni odnosi; odnos distribucijskih } \\
\text { kanala; odnos s kupcima; odnos s dobavljačima; } \\
\text { partnerski odnos; članstvo u registriranim i neregis- } \\
\text { triranim komercijalnim mrežama; vladini i drugi } \\
\text { korporativni odnosi }\end{array}$ & $\begin{array}{l}\text { Coviello and Munro, 1997; Zou and Stan, 1998; Styles and Ambler, } \\
\text { 2000; Crick and Jones, 2000; Li and Ogunmokun, 2001; Cadogan } \\
\text { et al., 2005; Ibeh and Wheeler, 2005; Styles et al., } 2008\end{array}$ \\
\hline
\end{tabular}


Table 1 Internal variables used in measurement of export performance (continuation)

Tablica 1. Unutarnje varijable upotrijebljene u procjeni odrednica izvoza (nastavak)

\begin{tabular}{|c|c|}
\hline Internal variables / Unutarnje varijable & References / Literatura \\
\hline $\begin{array}{l}\text { Company characteristics / Obilježja tvrtke } \\
\text { Company size / veličina tvrtke } \\
\text { Degree of internationalization / stupanj internacionali- } \\
\text { zacije } \\
\text { Company age / starost tvrtke } \\
\text { Industry sector - product type / industrijski sektor - } \\
\text { vrsta proizvoda } \\
\text { Organization culture / kultura organizacije } \\
\text { Financial resources / financijska sredstva } \\
\text { Ownership structure / vlasnička struktura }\end{array}$ & $\begin{array}{l}\text { Çulpan, 1989; Beamish et al. 1993; Hoang, 1998; Thirkell and Dau, } \\
\text { 1998; White et al., 1998; Piercy et al., 1998; Andersen and Moen, } \\
\text { 1999; Myers, 1999; Beamish et al., 1999; Shoham, 1999a; Shoham, } \\
\text { 1999b; Baldauf et al., 2000; Robertson and Chetty, 2000; Styles and } \\
\text { Ambler, 2000; Dean et al., 2000; Wolff and Pett, 2000; Francis and } \\
\text { Collins-Dodd, 2004; Gençtürk and Kotabe, 2001; Stöttinger and } \\
\text { Holzmüller, 2001; Richey and Myers, 2001; Albaum and Tse, 2001; } \\
\text { Li and Ogunmokun, 2001; Brouthers and Xu, 2002; Solberg, 2002; } \\
\text { O'Cass and Julian, 2003; Prasad et al., 2001; Rose and Shoham, } \\
\text { 2002; Shoham et al., 2002; Cadogan et al., 2005; Akyol and Ake- } \\
\text { hurst, 2003; Balabanis and Katsikea, 2003; Deng et al., 2002; } \\
\text { Chung, 2003; Dhanaraj and Beamish, 2003; Julien and Raman- } \\
\text { galahy, 2008; Morgan et al., 2004; Alvarez, 2004; Li, 2004; Chen et } \\
\text { al., 2004; Francis and Collins-Dodd, 2004; Lee and Griffith, 2004; } \\
\text { Yeoh,2004;Haahti et al., 2005; Cadogan et al., 2005; Brouthers and } \\
\text { Nakos, 2005; Contractor et al., 2007; Bekteshi, 2020 }\end{array}$ \\
\hline
\end{tabular}

Table 2 External variables used in measurement of export performance

Tablica 2. Vanjske varijable primijenjene za mjerenje obilježja izvoza

\begin{tabular}{|c|c|}
\hline External variables / Vanjske varijable & References / Reference \\
\hline $\begin{array}{l}\text { Characteristics of export market / Obilježja izvoznog } \\
\text { tržišta } \\
\text { Legal and political, Cultural similarity } \\
\text { Market competitiveness, Environmental competitive- } \\
\text { ness, Economic similarity, Channel accessibility } \\
\text { Customer exposure } \\
\text { zakoni i politika; sličnost kultura; tržišna konkurent- } \\
\text { nost; okolišna konkurentnost; gospodarska sličnost; } \\
\text { dostupnost kanala; izloženost kupaca }\end{array}$ & $\begin{array}{l}\text { White et al., 1998; Baldauf et al., 2000; Dean et al., 2000; } \\
\text { Robertson and Chetty, 2000; Brouthers and Xu, 2002; Rose and } \\
\text { Shoham, 2002; O'Cass and Julian, 2003; Balabanis and Katsikea, } \\
\text { 2003; Chen et al., 2004; Lee and Griffith, 2004; Morgan et al., } \\
\text { 2004; Cadogan et al., 2005; Lages and Montgomery, } 2004\end{array}$ \\
\hline $\begin{array}{l}\text { Domestic market features / Obilježja domaćeg tržišta } \\
\text { Domestic market conditions, Export support/ } \\
\text { uvjeti na domaćem tržištu; potpora izvozu }\end{array}$ & $\begin{array}{l}\text { Robertson and Chetty, 2000; Gençtürk and Kotabe, 2001; } \\
\text { Stöttinger and Holzmüller, 2001; Francis and Collins-Dodd, 2004; } \\
\text { Alvarez, 2002; Lages and Montgomery, } 2004\end{array}$ \\
\hline
\end{tabular}

Table 3 Economic factors used in measurement of export performance

Tablica 3. Ekonomski čimbenici primijenjeni u procjeni obilježja izvoza

\begin{tabular}{|c|c|}
\hline Economic factors / Ekonomski čimbenici & References / Literatura \\
\hline $\begin{array}{l}\text { Sales related / Vezani za prodaju } \\
\text { Export density / gustoća izvoza } \\
\text { Increase in export density / povećanje gustoće izvoza } \\
\text { Export sales efficiency / učinkovitost izvozne prodaje } \\
\text { Export sales growth / rast izvozne prodaje } \\
\text { Export growth compared to competitors / rast izvoza u } \\
\text { usporedbi s konkurentima } \\
\text { Return on investment in export sales / povrat ulaganja } \\
\text { u izvoznu prodaju } \\
\text { Export sales volume / opseg izvozne prodaje } \\
\text { Export sales volume compared to competitors / izvozna } \\
\text { prodaja u usporedbi s konkurentima }\end{array}$ & $\begin{array}{l}\text { Czinkota and Ronkainen, 1995; Çavuşgil, 1984; Cooper and Klein- } \\
\text { schmidt, 1985; Reid, 1983; Schlegelmilch and Ross, 1987; Çulpan, } \\
\text { 1989; Madsen, 1989; Walters and Samiee 1990; Axinn and Thach } \\
\text { 1990; Louteretal., 1991; Czinkota and Ursic, 1991; Chan, 1992; Ito } \\
\text { and Pucik, 1993; Walters, 1993; Kaynak and Kuan, 1993; Beamish } \\
\text { et al., 1993; Bodur, 1994; Crick and Jones, 2000; Akyol and Ake- } \\
\text { hurst 2003; Lim, Sharkey and Kim, 1996; Katsikeas et al., 2000; } \\
\text { Thirkell and Dau, 1998; Hoang, 1998; Wakelin, 1998; Piercy et al., } \\
\text { 1998; Styles et al., 2008; White et al., 1998; Shoham, 1999a; Hart } \\
\text { and Tzokas, 1999; Shoham 1999b; Myers, 1999; Beamish et al., } \\
\text { 1999; Andersen and Moen, 1999; Dean et al., 2000; Wolff and Pett, } \\
\text { 2000; Francis and Collins-Dodd, 2004; Baldauf et al., 2000; Stew- } \\
\text { art and McAuley, 2000; Yeoh, 2004; Styles and Ambler, 2000; Rob- } \\
\text { ertson and Chetty, 2000; Gençtürk and Kotabe, 2001; Richey and } \\
\text { Myers, 2001; Stöttinger and Holzmüller, 2001; Li and Ogunmokun, } \\
\text { 2001; Prasad et al., 2001; Brouthers and Xu, 2002; Shoham et.al., } \\
\text { 2002; Patterson, Cicic and Shoham, 1997; Rose and Shoham, 2002; } \\
\text { Solberg, 2002; Roper and Love, 2002; Cadogan et al., 2005; } \\
\text { Dhanaraj and Beamish, 2003; Balabanis and Katsikea 2003; Lages } \\
\text { and Montgomery, 2004; Morgan et al., 2004. }\end{array}$ \\
\hline
\end{tabular}


Table 3 Economic factors used in measurement of export performance (continuation)

Tablica 3. Ekonomski čimbenici primijenjeni u procjeni obilježja izvoza (nastavak)

\begin{tabular}{|l|l|}
\hline Market related / Vezani za tržište & Çavuşgil and Zou, 1994; Thirkell and Dau, 1998; White et al., \\
Export market share / udio u izvoznom tržištu & 1998; Piercy et al., 1998; Shoham, 1999a; Andersen and Moen, \\
Export market share by competitors / udio konkurenata & 1999; Myers, 1999; Robertson and Chetty, 2000; Albaum and Tse, \\
u izvoznom tržištu & 2001; Richey and Myers, 2001; Prasad et al., 2001; Baldauf et al., \\
Export market share growth / rast udjela na izvoznom & 2000; Brouthers and Xu, 2002; Cadogan et al., 2005; Rose and \\
tržištu & Shoham, 2002; Solberg, 2002; Dhanaraj and Beamish, 2003; Akyol \\
Export market share growth compared to competitors, & and Akehurst, 2003; Lages and Montgomery, 2004; Morgan et al., \\
Market solidarity & 2004. \\
Market diversification, Entry rate to new markets, & \\
Entry rate to new markets compared to competitors & \\
rast udjela izvoznog tržišta u usporedbi s konkuren- & \\
tima; tržišna solidarnost; diversifikacija tržišta; stopa & \\
ulaska na nova tržišta; stopa ulaska na nova tržišta u & \\
usporedbi s konkurentima & \\
\hline
\end{tabular}

Table 4 Non-economic factors used in measurement of export performance

Tablica 4. Neekonomski čimbenici primijenjeni za mjerenje obilježja izvoza

\begin{tabular}{|c|c|}
\hline Non-economic factors / Neekonomski čimbenici & References / Literatura \\
\hline $\begin{array}{l}\text { General / Općenito } \\
\text { Export success / uspjeh izvoza } \\
\text { Rating of export performance compared to competitors / ocjena } \\
\text { provedbe izvoza u usporedbi s konkurentima } \\
\text { Overall export performance / ukupni izvozni učinak } \\
\text { Overall export performance compared to competitors / ukupni } \\
\text { izvozni učinak u usporedbi s konkurentima } \\
\text { Strategic export performance / strateška provedba izvoza }\end{array}$ & $\begin{array}{l}\text { Seifert and Ford, 1989; Raven, McCullogh and Tansu- } \\
\text { haj, 1994; Singer and Czinkota 1994; Katsikeas et al., } \\
\text { 1996; Patterson, Cicic and Shoham, 1997; Styles et al., } \\
\text { 2008; White et al., 1998; Thirkell and Dau, 1998; An- } \\
\text { derson and McAuley, 1999; Andersen and Moen, 1999; } \\
\text { Myers, 1999; Styles and Ambler, 2000; Robertson and } \\
\text { Chetty, 2000; Stewart and McAuley, 2000; Crick and } \\
\text { Jones, 2000; Gençtürk and Kotabe, 2001; Li and } \\
\text { Ogunmokun, 2001; Prasad et al., 2001; Shoham et al., } \\
\text { 2002; Solberg, 2002; Brouthers and Xu, 2002; O'Cass } \\
\text { and Julian, 2003; Akyol and Akehurst, 2003; Balabanis } \\
\text { and Katsikea, 2003; Lages and Montgomery, 2004; } \\
\text { Manzanares, 2019; Imran et al.2020 }\end{array}$ \\
\hline $\begin{array}{l}\text { Others / Drugi čimbenici } \\
\text { Achieving targets related to reaction to competition pressure, } \\
\text { Awareness and image creation in export market, } \\
\text { Contribution of export to the growth of the company and the } \\
\text { contribution of the management quality of the company } \\
\text { Customer satisfaction, New technology - expertise, Product-service } \\
\text { quality } \\
\text { Quality of customer relations, Quality of distributor relations, } \\
\text { Reputation of the company } \\
\text { postizanje ciljeva vezanih za reakciju na pritisak konkurencije; } \\
\text { svjesnost i stvaranje dojma na izvoznom tržištu; doprinos izvoza } \\
\text { rastu poduzeća i doprinos kvalitete upravljanja; zadovoljstvo } \\
\text { kupaca; nova tehnologija/stručnost; kvaliteta proizvoda/usluga; } \\
\text { kvaliteta odnosa s kupcima; kvaliteta odnosa s distributerima; } \\
\text { ugled tvrtke }\end{array}$ & $\begin{array}{l}\text { Thirkell and Dau, 1998; Myers, 1999; Prasad et al., } \\
\text { 2001; Gençtürk and Kotabe, 2001; Morgan } \text { et al., 2004; } \\
\text { Manzanares, 2019; Imran et al. } 2020\end{array}$ \\
\hline
\end{tabular}

tics, attitudes, and strategies of the companies were collected by a total of 95 questions, 51 items of which are in 7 points likert scale, and 32 of which consist of mostly open-ended, ratio scale and some nominal scale questions on the characteristics of companies.

The 1-7 interval scale is used, 1 referring to "strongly disagree", 4 referring to "not agree/disagree", and 7 referring to "strongly agree".

As the random process was not used in sampling, the evaluations obtained from the analysis represent the properties and attitudes of 182 companies. Based on the literature research, it was decided to examine all the influential variables in determining the exporting of the furniture industry; accordingly the attitudes/trends of the companies in terms of 51 items and eight factors listed below were measured, in order to determine the effective items/factors in exporting (Table 5).

The listed items, evaluated in the following tables are selected according to conducted factor analyses for each dimension, separately. The scores of 51 items selected out of 63 items are the arithmetic means of the item attitude scores attributed by companies, and 
Table 5 List of variables used in the study

Tablica 5. Popis varijabli primijenjenih u istraživanju

\begin{tabular}{|c|c|}
\hline $\begin{array}{l}\text { 1. Factor: Brand-advertisement-packaging } \\
\text { 1. čimbenik: brend/reklama/pakiranje }\end{array}$ & $\begin{array}{l}\text { 5. Factor: Environmental and economic } \\
\text { 5. čimbenik: okoliš i gospodarstvo }\end{array}$ \\
\hline $\begin{array}{l}\text { The importance of internet sites in promotion / važnost internetskih } \\
\text { stranica u promociji } \\
\text { Congress fair participation / sudjelovanje na kongresima } \\
\text { Promotion of new product in short time / promocija novog } \\
\text { proizvoda u kratkom vremenu } \\
\text { Advertisement promotion activities / promotivne aktivnosti putem } \\
\text { oglašavanja } \\
\text { Giving importance to packaging / pridavanje važnosti pakiranju } \\
\text { Being a brand of every product / težnja da svaki proizvod bude } \\
\text { brend } \\
\text { Being a recognized brand / biti priznati brend } \\
\text { Not having a marketing problem / nema marketinških problema }\end{array}$ & $\begin{array}{l}\text { Internal market shrinkage / smanjenje unutarnjeg } \\
\text { tržišta } \\
\text { Export to EU countries / izvoz u zemlje EU-a } \\
\text { Distance to market / udaljenost od tržišta } \\
\text { Cultural similarity with market / kulturološka } \\
\text { sličnost s tržištem } \\
\text { Attention to demographic characteristics / briga o } \\
\text { demografskim obilježjima } \\
\text { Change in exchange rates / promjena tečaja } \\
\text { Effect of interest rates / učinak kamatnih stopa }\end{array}$ \\
\hline $\begin{array}{l}\text { 2. Factor: Customer satisfaction } \\
\text { 2. čimbenik: zadovoljstvo kupaca }\end{array}$ & $\begin{array}{l}\text { 6. Factor: Management style and format } \\
\text { 6. čimbenik: način i format upravljanja }\end{array}$ \\
\hline $\begin{array}{l}\text { Complaint for product / prigovor na proizvod } \\
\text { On-time delivery / pravodobna dostava } \\
\text { Compliance with technical requirements / sukladnost s tehničkim } \\
\text { zahtjevima } \\
\text { Customer expectation in new product / očekivanja kupaca vezana } \\
\text { za novi proizvod } \\
\text { Quality based satisfaction / zadovoljstvo kvalitetom } \\
\text { Price based satisfaction / zadovoljstvo cijenom } \\
\text { Design based satisfaction / zadovoljstvo dizajnom } \\
\text { Technical team for customer satisfaction / tehnički tim zadužen za } \\
\text { zadovoljstvo kupaca } \\
\text { Satisfying warranty period / zadovoljavajući jamstveni rok }\end{array}$ & $\begin{array}{l}\text { Compliance with export / usklađenost s izvozom } \\
\text { Desire and support for exporting / želja za } \\
\text { izvozom i potpora izvozu } \\
\text { Appreciating export opportunities / poštovanje } \\
\text { izvoznih mogućnosti } \\
\text { Having export motivation / postojanje motivacije } \\
\text { za izvoz }\end{array}$ \\
\hline $\begin{array}{l}\text { 3. Factor: Competition status } \\
\text { 3. čimbenik: status konkurencije }\end{array}$ & $\begin{array}{l}\text { 7. Factor: Research and development activities } \\
\text { 7. čimbenik: istraživačke i razvojne aktivnosti }\end{array}$ \\
\hline $\begin{array}{l}\text { Fast adaptation to demand / brza prilagodba potražnji } \\
\text { Not worrying about the new competition / suvišnost brige o novoj } \\
\text { konkurenciji } \\
\text { Determination of sales price by competitors / određivanje prodajne } \\
\text { cijene ovisno o konkurenciji } \\
\text { Taking the quality document easily / jednostavno preuzimanje } \\
\text { dokumenata o kvaliteti } \\
\text { New market research being pioneer in price determination / novo } \\
\text { istraživanje tržišta kao pionirski korak u određivanju cijena } \\
\text { Ensuring price advantage / osiguranje cjenovne prednosti } \\
\text { Possessing competitive power in the industry / posjedovanje } \\
\text { konkurentske moći u industriji } \\
\text { Developing different strategies for different products / razvijanje } \\
\text { različitih strategija za različite proizvode }\end{array}$ & $\begin{array}{l}\text { Pioneer in new product / pionirska uloga u } \\
\text { razvoju novih proizvoda } \\
\text { Eco-friendly / ekološka prihvatljivost } \\
\text { Innovative in ARGE / inovativnost u ARGE-u } \\
\text { Having detailed information about the market / } \\
\text { posjedovanje detaljnih informacija o tř̌ištu } \\
\text { Following technology / praćenje tehnologije }\end{array}$ \\
\hline $\begin{array}{l}\text { 4. Factor: Export structure } \\
\text { 4. čimbenik: struktura izvoza }\end{array}$ & $\begin{array}{l}\text { 8. Factor: Personnel status } \\
\text { 8. čimbenik: status osoblja }\end{array}$ \\
\hline $\begin{array}{l}\text { Pioneering in exporting / pionirski izvoz } \\
\text { Having an export strategy / posjedovanje izvozne strategije } \\
\text { Having an export organization / postojanje organizacije izvoza } \\
\text { Receiving professional support in the export strategy / primanje } \\
\text { stručne potpore u izvoznoj strategiji } \\
\text { Export agreement period / razdoblje ugovora o izvozu } \\
\text { Making export in the last } 5 \text { years / izvoz u posljednjih pet godina }\end{array}$ & $\begin{array}{l}\text { In-service training / stručno usavršavanje } \\
\text { Provision of qualified personnel / osiguranje } \\
\text { kvalificiranog osoblja } \\
\text { Employee ambience satisfaction / zadovoljstvo } \\
\text { korisnika sredinom }\end{array}$ \\
\hline
\end{tabular}

factor scores of these eight factors are the means of the item scores of the factor members.

The variables obtained from 32 open-ended questions are:

- Equity (\$)

- Management Type (Individual/Family Company, Corporate Company)

- Advertising Expenditure (\$)

- Manager's Experience Abroad (year)
- Legal Form of the Company (Ordinary, Joint Stock or Limited Liability, Limited Partnership, Collective)

- $\quad$ Automation Utilization Rate (\%)

Scenarios were produced with the help of algorithms called J48 and decision trees were formed with the variables that were more effective in these scenarios. All of the analyses were done with the software called WEKA. WEKA is a Data Mining application develop- 
ment program that started as a project and today it is used by many people around the world. WEKA is an open code program developed on the Java platform.

\subsection{Decision trees and pruning \\ 2.1. Stabla odlučivanja i obrezivanje}

Decision trees are an important machine learning algorithm used in many areas. The $\mathrm{J} 48$ algorithm is a decision tree classification algorithm. Decision trees are widely used because they are easy to evaluate and perceive, and they do not need to satisfy as much assumptions as the regression models. The J48 algorithm consists of two steps. The first is the process of forming the structure of the tree and the second is pruning (Gümüşçü et al., 2016). In this study, J48 classification algorithm developed by J. Ross Quinlan was used.

Decision trees consist of a root, nodes, branches and leaves. The top part of the tree is called root and the bottom part is called leaf. Each attribute in the data set represents the nodes. The parts that provide the connection between the nodes are called branches.

The most important process step in forming decision trees is to decide which branching will take place according to quality value (Kavzaoğlu and Çölkesen, 2010). Knowledge gain (Equation 1), gini index (Equation 2) and towing rule (Eq. 3) are commonly used as decision-making criteria (Gümüşçü et al., 2016).

Assuming that if the number of classes is $\mathrm{h}$ and these class values are repeated as $T$, then the probability value of a class is as in Eq. 1.

$$
P_{\mathrm{i}}=\frac{C_{\mathrm{i}}}{|T|}
$$

$C_{\mathrm{i}}$ represents the number of class values in a class. If the entropy value of this class is $H(T)$, it is as in Eq. 2.

$$
H(T)=-\sum_{\mathrm{i}=1}^{\mathrm{n}} P_{\mathrm{i}} \log _{2} P_{\mathrm{i}}
$$

Considering that $T$ class values are subdivided into $T_{1}, T_{2} \ldots, T_{\mathrm{n}}$ according to $Y$ attribute values in the data set, the information gain that can be obtained by dividing the $T$ class values by using $Y$ attribute values is as in Eq. 3.

$$
I G(Y, T)=H(T)-\sum_{\mathrm{i}=1}^{\mathrm{n}} \frac{\left|T_{\mathrm{i}}\right|}{|T|} H\left(T_{\mathrm{i}}\right)
$$

In calculating the value of the attribute, the dissociation information is calculated as in Eq. 4.

$$
S I(Y)=-\sum_{\mathrm{i}=1}^{\mathrm{n}} \frac{\left|T_{\mathrm{i}}\right|}{|T|} \log _{2}\left(\frac{\left|T_{\mathrm{i}}\right|}{T}\right)
$$

The amount of information gain is obtained by the ratio of the information gain to the dissociation information (Equation 4). In this way, the tree structure is created according to the quality with the highest earnings information by finding earnings information for each attribute (Gümüşçü et al., 2016).

In addition to obtaining the structure of decision trees, pruning is another important process. Pruning can be done in two ways. When the tree structure is obtained, the process of stopping the division to prevent the tree to grow further is called pre-pruning. As another method, after the tree structure is completely formed, the nodes considered to be excessive are removed. This pruning process is known as the last pruning (Quinlan, 1999).

\subsection{Evaluation of classification result}

2.2. Evaluacija rezultata klasifikacije

To measure the success of the classification, it is not enough to look at the accuracy rate. The recall and precision values of the classification process also provide information about the success of the classification.

Accuracy Ratio: The ratio of the number of correctly classified samples to the total number of samples.

$$
\text { Accuracy }=\frac{T P+T N}{\text { Total Sample Count }}
$$

TP (True positive): It means that it does export for export company.

FP (False positive): It means that it does export for non-exporting company.

TN (True negative): It means that it does not export to the non-exporting company.

FN (False negative): It means that it does not export to the exporting company.

In this case, the confusion matrix is formed as follows (Table 6):

Recall: The rate of correct detection of non-export.

$$
\text { Recall }=\frac{T P}{T P+F N}
$$

Precision: The ratio of those who cannot actually export and those who cannot export.

$$
\text { Precision }=\frac{T P}{T P+N P}
$$

There is a conflict between the two important scales. To eliminate this, the F score is measured. The

\begin{tabular}{|c|c|c|c|}
\hline \multicolumn{2}{|c|}{ Actual / Stvaran } & & \\
\hline Positive / Pozitivan & Negative / Negativan & & \\
\hline $\begin{array}{c}\text { True positive } \\
\text { stvarno pozitivan }\end{array}$ & $\begin{array}{c}\text { False negative } \\
\text { lažno negativan }\end{array}$ & $\begin{array}{l}\text { Positive } \\
\text { pozitivan }\end{array}$ & \multirow{2}{*}{$\begin{array}{l}\text { Prediction } \\
\text { predviđanje }\end{array}$} \\
\hline $\begin{array}{l}\text { False negative } \\
\text { lažno negativan }\end{array}$ & $\begin{array}{c}\text { True negative } \\
\text { stvarno negativan }\end{array}$ & $\begin{array}{l}\text { Negative } \\
\text { negativan }\end{array}$ & \\
\hline
\end{tabular}
$\mathrm{F}$ score uses the harmonic mean to be able to ignore extreme values.

$$
F_{\text {Score }}=2 \times \frac{\text { Precision } \times \text { Recall }}{\text { Precision }+ \text { Recall }}
$$

Table 6 Confusion matrix

Tablica 6. Matrica konfuzije 


\subsection{ROC curve (Receiver Operating Characteristic} Curve)

2.3. ROC krivulja (karakteristična krivulja rada prijamnika)

ROC Curve is used frequently in the success calculations of classification models. It is basically calculated over two values.

TPR (True Positive Ratio): It means the sensitivity ratio in detecting exporting companies.

$$
T P R=\frac{T P}{T P+F N}
$$

FPR (False Positive Ratio): It is the rate of determining that means "it does export" to non-exporting companies.

$$
F P R=\frac{F P}{F P+F N}
$$

When these two values are placed on the $\mathrm{x}$ and $\mathrm{y}$ axes, the area under the line (AUC) is calculated and the TPR and FPR ratios are determined against the limit values falling along the curve. For each limit value, precision and recall values are calculated and the limits that make the F score maximum are selected. In fact, the larger the area below the line, the higher the success rate of the model. The higher the $F$ score, the higher is the area under the line (Ş1k, 2014; Aydemir, 2017, Langloisa and Frank; 2011).

Sensitivity (Recall or True positive rate): Sensitivity is calculated as the number of correct positive predictions divided by the total number of positives. It is also called recall (REC) or true positive rate (TPR). The best sensitivity is 1.0 , whereas the worst is 0.0 . Sensitivity is calculated as the number of correct positive predictions (TP) divided by the total number of positives $(\mathrm{P}=\mathrm{TP}+\mathrm{FN})$ (Langloisa and Frank; 2011).

Kappa statistic: Kappa statistic is called the accuracy measure of the prediction. Kappa takes a value between 0 and 1 . If kappa is between 0.4 and 0.6 , a moderate fit is achieved. If the Kappa value is between 0.6 and 0.8 , it means that there is a good level of prediction. A very good level of harmony is achieved between Kappa 0.8 and 1 (Landis and Koch, 1977).

\section{RESULTS}

\section{REZULTATI}

The variables used in this section have been determined through the regression and logistic regression analyses, which are more effective in exporting, taking into account the findings obtained above. In order to create healthy models in the scenarios, these preliminary analyses were performed in order to find the variables that might have the ability of representation in the model. These variables are modeled with decision trees on the basis of WEKA with different scenarios.

\subsection{Scenario 1 and findings}

3.1. Scenarij 1. i zaključci

The first model included variables such as Shareholders' Equity, Management Type, Legal Form of the Company, Sales Revenues, Partnership Status, Per- centage of Automation Usage, Advertising Expenditures, Product Development Expenditures. In order to reach a more accurate result, surveys that did not include the Equity and Advertising Expenditures data were excluded from the evaluation. In this case, a total of 68 companies were evaluated. As a result of J48 algorithm, the number of correctly classified data is 66 and the number of incorrectly classified data is 2 . The model is classified with an accuracy of $97.1 \%$.

As a result of the evaluation of $\mathrm{J} 48$ decision tree algorithm, it was seen that the variables of Equity, Management Type and Advertising Expenditures, which were initially included in the model, had more meaningful explanations. Since the equity variable has the highest entropy, the decision tree started branching with this variable. It was concluded that furniture companies with equity higher than $\$ 77,000$ can export.

According to Figure 2, the second-high entropy Management Type variable leads the decision tree for companies whose equity capital is below $\$ 77,000$. According to this variable, the management style of the companies shows that they can export even if their equity is below $\$ 77,000$. However, for companies managed as Family Business, the Advertising spending variable is the final decision maker of the decision tree. Accordingly, it is seen that the companies that are family companies and that allocate more than $\$ 10,000$ for Advertising Expenditures can export. Finally, it was concluded that the companies that allocate $\$ 10,000$ or less budget for advertising expenditures cannot export.

In this Scenario, the following conditions are necessary for a company to export;

1. If the equity is more than $\$ 77,000$,

2. Although the equity is less than $\$ 77,000$, if the firm is managed as a corporate company,

3 . If it is a family owned company with an equity capital of less than $\$ 77,000$, it can export if it allocates more than $\$ 10,000$ to the advertising expenditure.

In the decision tree model obtained by using J48 algorithm in WEKA program, the number of leaves was 4 and the length of the tree was 7 . It was found that the variables included in the model accounted for $97 \%$ of the structure of the decision tree. This result shows that the model is descriptive. When talking about the success of a model, it was only mentioned in the method part of this paper that the accuracy rate alone would not make sense. Accuracy value and recall value were found to be 0.971 . The ROC area value was calculated as 0.907 and the F score was 0.971 , so the model was very successful. The accuracy measure of the prediction, kappa statistic, was found to be 0.817 and proved that the prediction showed a very good level of fit.

\subsection{Scenario 2 and findings}

3.2. Scenarij 2. i zaključci

In Scenario 2 established with WEKA, all the factors, the manager's experience abroad and the legal form of the company were used as input. The Export Structure Factor was the first node of the decision tree.

According to this scenario, it is seen that no company without a score for the Export Structure factor 
.... Aytekin, Pekkaya: Determining the Competencies Necessary for Exporting in Furniture...

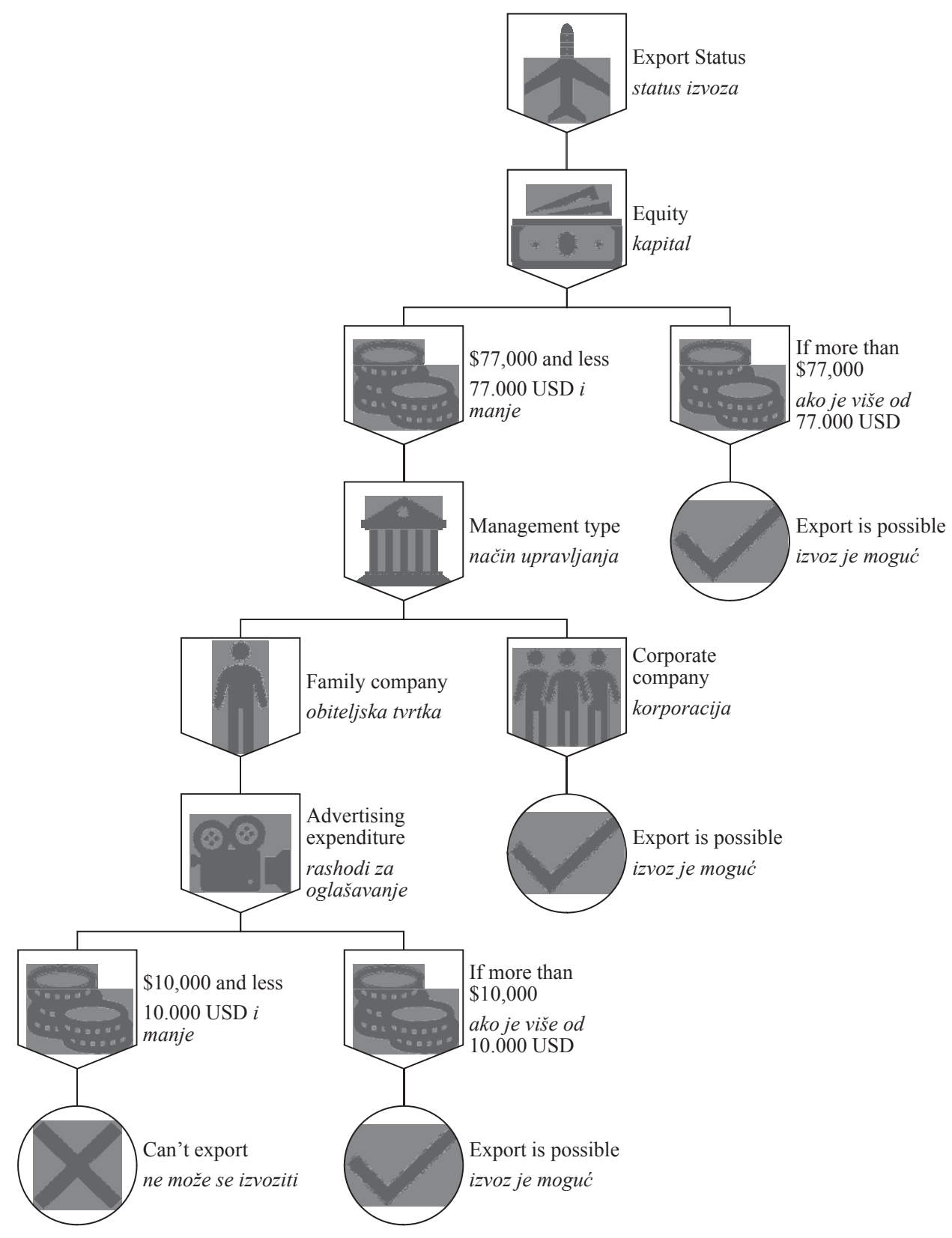

Figure 2 Decision tree model for Scenario 1

Slika 2. Model stabla odlučivanja za 1. scenarij

can export (Figure 3). This factor in the decision tree should not be taken into account in the comments, as this Export Structure factor is only taken into account in exporting companies. Since this Scenario included the manager's experience abroad at a critical level of 4 years, the interpretation of the scenario was considered original. If the Export Structure factor is higher than zero, the overseas experience of the Manager plays an important role in the decision tree. Accordingly, if the manager has overseas experience for more than 4 years, it can be said that this company exports easily. If it is a company with a manager who has less than 4 years of experience abroad, it can export only if it is a Joint Stock Company or a Limited Company.

If the firm is a common, limited partnership or a collective company, the Competitiveness factor appears to be prominent. Accordingly, if the Competitive Status factor score is above 5.5, the fact that the com- pany manager has more than 2 years of experience means that the company can export. However, if the manager has 2 years or less experience abroad, this company cannot export.

If the Company's Competitiveness factor has a value of 5.5 or less, the Staff Situation factor comes into play. It is not possible for a company whose personnel situation score is zero to export. It is determined that if the value of Personnel Situation factor is higher than 0 and if the Competitive Status factor is less than 5.5 , this company can export.

In this scenario, the following conditions are necessary for a company to export;

1. If the Export Structure factor score is greater than zero and the manager's overseas experience is more than 4 years,

2. If the Export Structure factor is greater than zero and the manager's overseas experience is 4 years or less, 


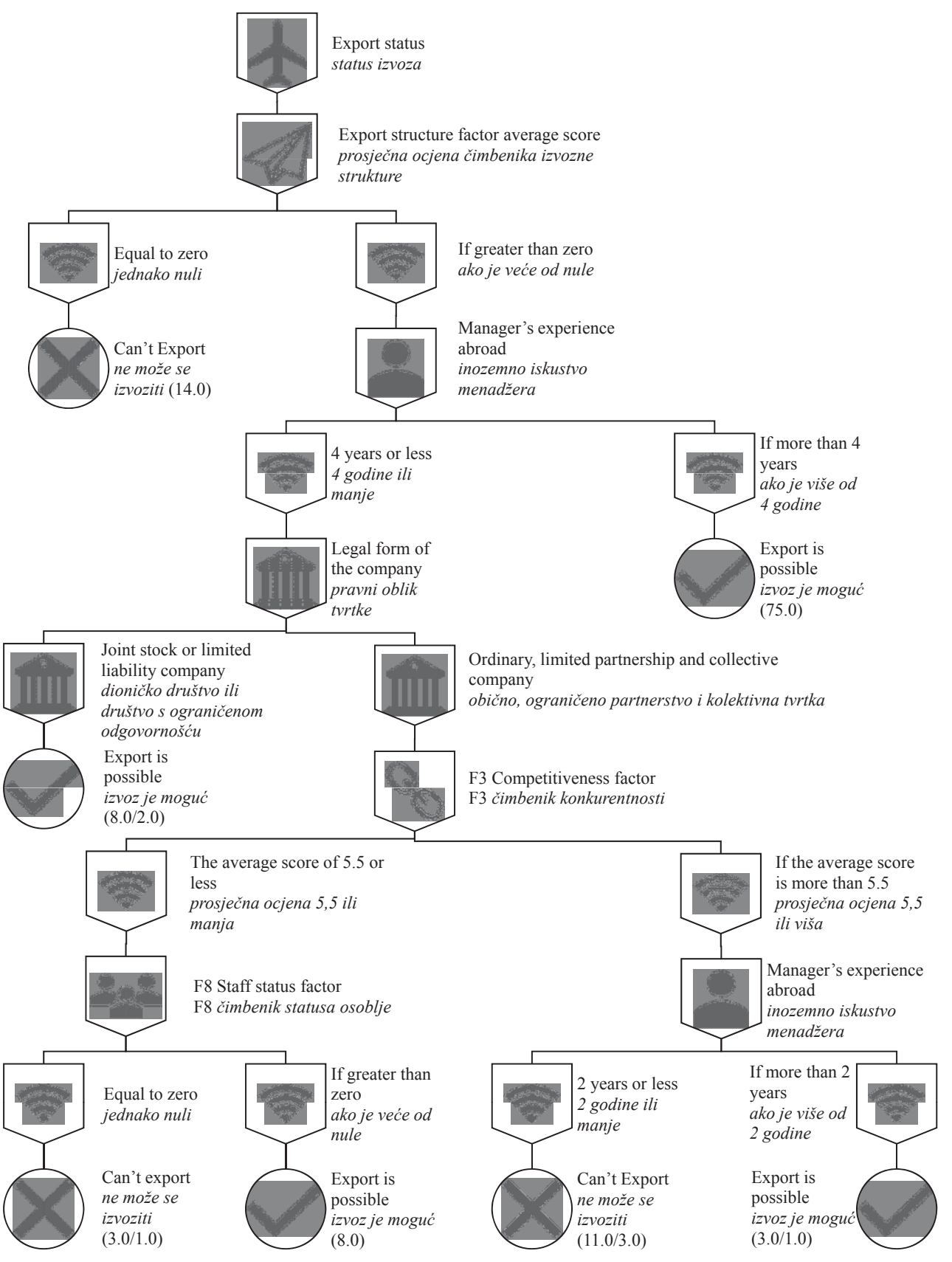

Figure 3 Decision tree model for Scenario 2

Slika 3. Model stabla odlučivanja za 2. scenarij

provided the legal form of the firm is limited or joint-stock company,

3. If the Export Structure factor is greater than zero, the manager's overseas experience is less than 4 years and the Competition Status score is less than 5.5, and the Staff Situation score is greater than zero,

4. If the Export Structure factor is greater than zero, the manager's overseas experience is less than 4 years and the Competition Status score is more than 5.5 and if the manager's overseas experience is between 2 and 4 years.

The accuracy of the scenario was found to be $94.5 \%$. This means that only 10 out of 182 companies were misclassified. Accuracy value was calculated as 0.945 and recall value was calculated as 0.945 . The ROC Area value was 0.968 and the F score was 0.945 . These values mean that the model is quite successful.
The accuracy measure of the prediction, kappa statistic, was found to be 0.836 and proved that the prediction showed a very good level of fit.

\subsection{Scenario 3 and findings}

\subsection{Scenarij 3. i zaključci}

The variables used in Scenario 3 were Competitiveness, Export Structure, Personnel Situation, Manager's overseas experience, logarithm of this variable, Equity, Legal Structure of the Company, Automation Utilization Rate and Advertising Expenditures. According to these variables, for the scenario in Figure 4 , the experience of the manager abroad is the most important factor for a company to export. If the manager has any overseas experience, even for a very short time, it means that the company he works for can easily export (131 companies). However, if the 
.... Aytekin, Pekkaya: Determining the Competencies Necessary for Exporting in Furniture...

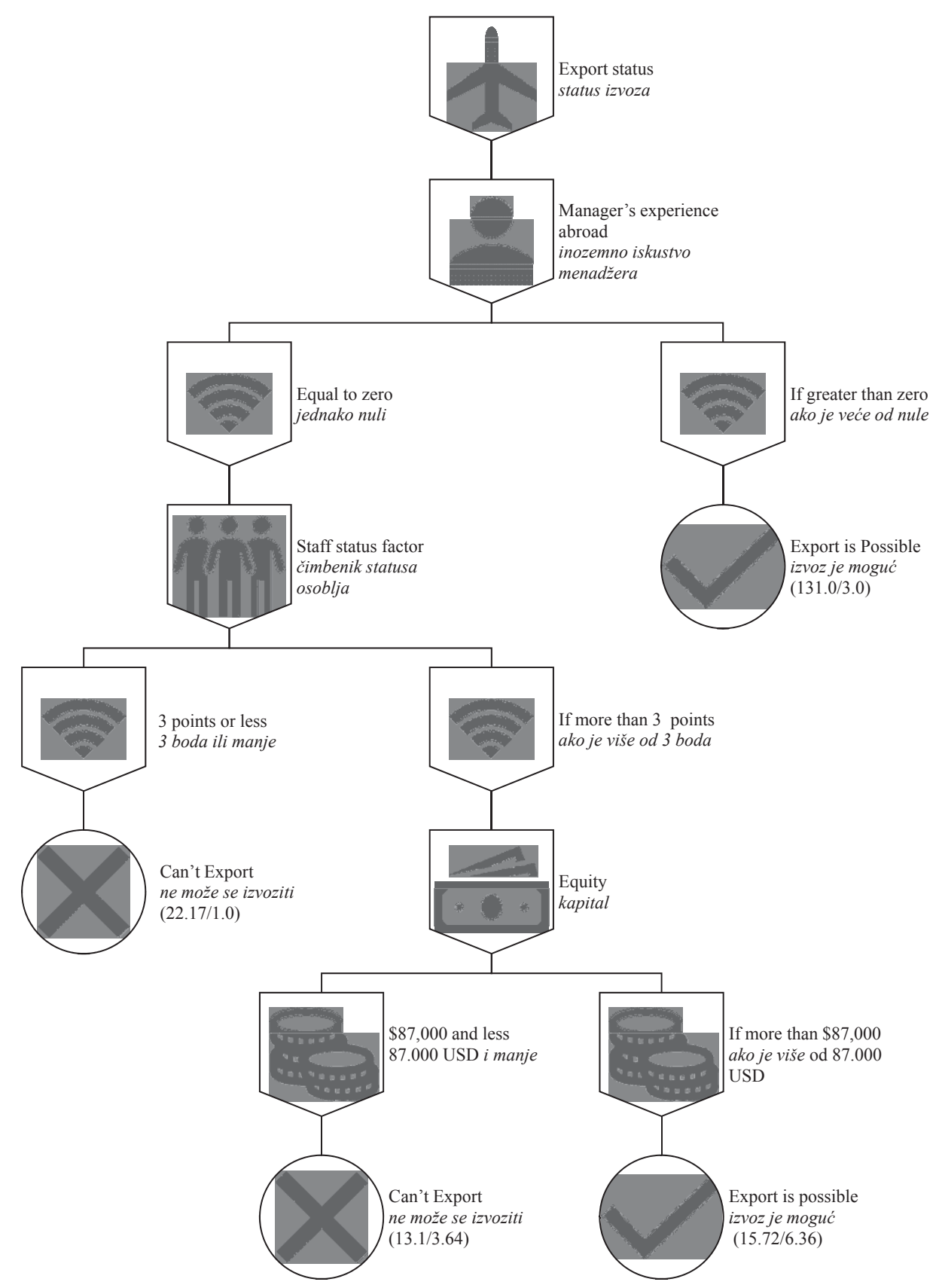

Figure 4 Decision tree model for Scenario 3

Slika 4. Model stabla odlučivanja za 3. scenarij

manager has no experience abroad, the most important factor in the decision tree is the staff situation. Accordingly, it is concluded that companies whose average score is 3 or less cannot export. However, it is possible to decide whether the companies whose Staff Situation factor is higher than 3 can export by looking at the third important issue, equity. Accordingly, it was concluded that companies with an equity capital of $\$ 87,000$ and below could not export and companies with an equity of $\$ 87,000$ or more could export.

In this Scenario, the following conditions are necessary for a company to export;

1. If the Manager has overseas experience,

2. If the Manager has no overseas experience, the firm can export if the Staff Situation factor score is greater than 3 and the Equity is greater than $\$ 87,000$.
The accuracy rate of the Scenario was found to be $92.9 \%$. This means that only 13 out of 182 companies were misclassified. Accuracy value was calculated as 0.932 and recall value was calculated as 0.929 . ROC Area value was 0.947 and F score was 0.930 . These values mean that the model is quite successful. The accuracy measure of the prediction, kappa statistic, was found to be 0.801 and proved that the prediction showed a very good level of fit.

\subsection{Scenario 4 and findings}

3.4. Scenarij 4. i zaključci

This Scenario that resulted from another model used the following variables: Competitive Status, Export Structure, Personnel Situation, Manager's overseas experience, Equity, Advertising Expenditures, Legal Structure of the Company, and Automation 


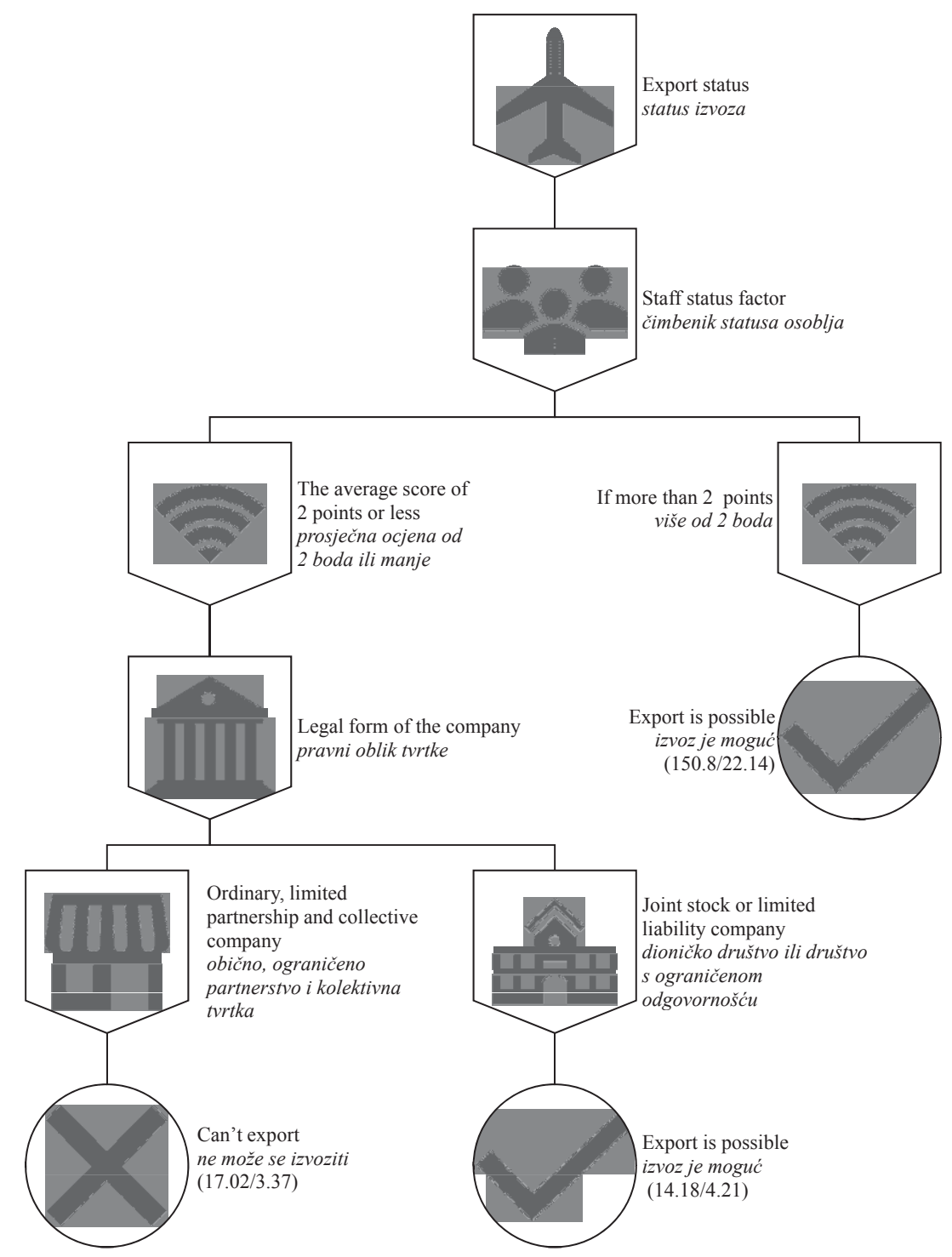

Figure 5 Decision tree model for Scenario 4

Slika 5. Model stabla odlučivanja za 4. scenarij

Utilization Rates. In this Scenario, Staff Situation, Qualified Personnel Procurement, In-Service Training and Personnel Environment Satisfaction are the most important factors. Accordingly, it is seen that companies with an average value of more than 2 can export. If the Staff Situation factor is less than 2 or 3 , the Firm's Legal Form plays an important role in the decision tree. Accordingly, although the Staff Situation is less than 2, it is seen that companies with limited or joint stock status can export. However, if the legal form of the firm is Ordinary Company, Limited Partnership, Shared Limited Partnership or Collective Company, export is not possible.

According to this Scenario, in order for a firm to export, the Staff Situation factor score must be greater than 2 (Figure 5). If the Staff Situation factor score is 2 or less, the legal form of the firm should be Limited or Joint Stock Company. It was concluded that the Staff Situation factor score was 2 or less and the firm could not export if the legal form of the firm was ordinary, limited partnership or collective company.

In this Scenario, the following conditions are necessary for a firm to export;
1. If the Staff Situation factor score is greater than 2 ,

2. If the Staff Situation factor score is less than 2, the firm may export if the legal form is limited liability or joint stock.

The accuracy rate of the scenario was found to be $92.9 \%$. This means that only 13 out of 182 companies were misclassified. Accuracy value was calculated as 0.932 and recall value was calculated as 0.929 . ROC Area value was 0.947 and $F$ score was 0.930 . These values mean that the model is quite successful. The accuracy measure of the prediction, kappa statistic, was found to be 0.801 and proved that the prediction showed a very good level of fit.

\subsection{Scenario 5 and findings}

3.5. Scenarij 5. i zaključci

The variables used as inputs in this Scenario are Brand-Advertisement-Packaging, Competition Status, Export Structure, Economic and Environmental Factors, Management Style and Style, R \& D Activities, Staff Situation, Manager's overseas experience, legal form of the company, automation and advertising expenditures. 
.... Aytekin, Pekkaya: Determining the Competencies Necessary for Exporting in Furniture...

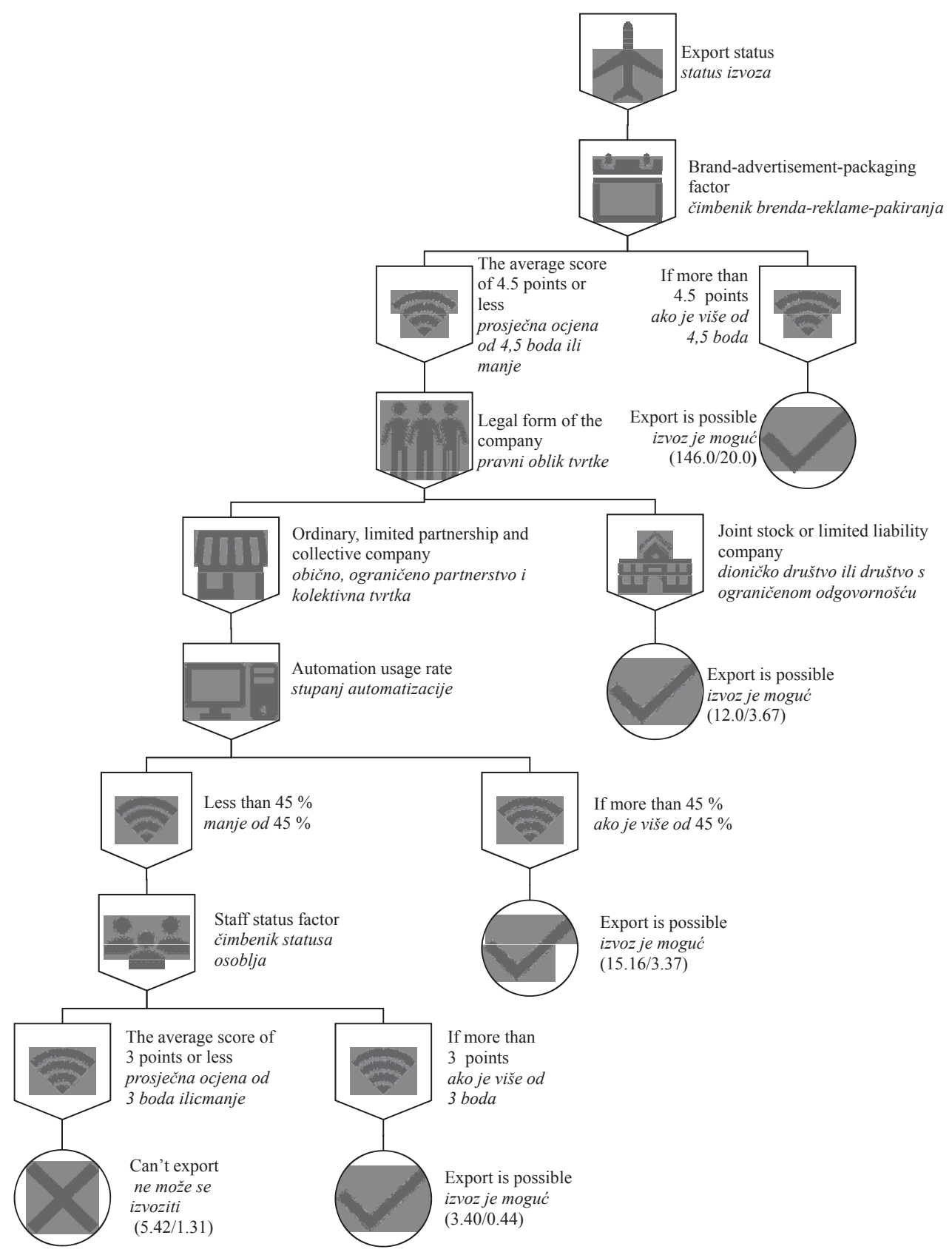

Figure 6 Decision tree model for Scenario 5

Slika 6. Model stabla odlučivanja za 5. scenarij

In this scenario, the knots of the decision tree are Brand-Advertisement-Packaging factor, Legal structure of the company, Automation usage rate and Staff Situation factor.

According to this Scenario, a company must meet the following conditions in order to export (Figure 6):

1. Brand-Packaging-Advertising factor score should be higher than 4.5,

2. If Brand-Packaging-Advertising factor score is 4.5 or less, Legal Form should be Joint Stock or Limited Liability,

3. If the brand-packaging-advertising factor score is 4.5 or less and the legal form is ordinary, limited partnership or collective company, the automation usage rate should be more than $45 \%$,

4. If the Brand-Packaging-Advertising factor score is 4.5 or less and the legal form is ordinary, limited or collective company and the automation rate is less than $45 \%$, the Staff Situation factor score should be higher than 3 .

If the above conditions are not fulfilled, it is concluded that a company cannot export under this Scenario.

The accuracy rate of the Scenario was found to be $84.6 \%$. This means that 28 out of 182 data were misclassified. Accuracy value was calculated as 0.842 and recall value was calculated as 0.946 . ROC Area value was 0.720 and $F$ score was 0.835 . These values mean that the model is successful. The accuracy measure of the prediction, i.e. kappa statistic, is found to be 0.476 , proving that the prediction shows a moderate fit.

\subsection{Overview of scenarios}

3.6. Pregled scenarija

In order to examine the scenarios as a whole, all the factors used and the subjects that cause branching 
in the scenarios are discussed. The expressions shown in Scenario 1 (S1) to Scenario 5 (S5) show the scenario numbers and alternative ways to export in each scenario.

Consequently, there are 2 alternative routes in S3 and $\mathrm{S} 4,3$ alternative routes in $\mathrm{S} 1$ and $\mathrm{S} 2$, and 4 alternative routes in $\mathrm{S} 5$.

In examining the findings of the scenarios, it can be seen that the staff situation factor comes to the fore in 4 scenarios. This is followed by the legal form of the company. Whether the legal form of the company is Joint Stock Company or Limited Company has been decisive in 3 scenarios. Overseas experience of the manager and equity have been identified as effective in 3 scenarios.

These findings show that the determination of the factors affecting the export, which constitutes the main subject of the study, is correct.

\section{DISCUSSION AND CONCLUSIONS 4. RASPRAVA I ZAKLJUČAK}

Export is an important opportunity that increases the welfare and competitiveness of countries. Thanks to exports, companies increase their sales, profits, capacity utilization, competitiveness, employment in the country, share in world markets and reduce foreign trade deficit.

In the last 5 years, the furniture industry has become an important economic industry with an annual value of 376 billion dollars. Socio-economic aspects of employment are also of considerable importance. In terms of furniture production and trade, EU countries have developed considerably compared to many regions of the world. Especially Germany and Italy are ahead of other European countries in terms of production, import and consumption. China has been a leader in furniture production in the world and has been leading the industry for the last five years. There is a significant potential for development and growth of the furniture industry in Turkey. When the furniture industry in Turkey is examined, it can be seen that the furniture companies aim to increase the export share by more than $2 \%$ (Anadolu Agency, 2017).

Export performance is generally defined as the success of a company in international sales. Despite many studies to determine the determinants of export performance, there is no consensus on these determinants (Aaby and Slater, 1989; Madsen, 1989; Shoham, 1999a; Zou and Stan 1998). In various studies, it is seen that different export performance indicators and different measurements are used. This situation causes difficulties in the comparison of the studies. Therefore, in this study, efforts were made to identify common indicators that can evaluate export performance and measurements related to the issues affecting export.

In order to identify the factors affecting the export performance of the furniture industry in Turkey, a comprehensive literature study was carried out on companies engaged in the production of furniture by combining the factors and issues obtained in a survey of 182 furniture firms. The aim is to convey the findings to the executives, investors, decision makers and even academicians interested in the export industry.

In the study, efforts were made to draw meaningful results from the data obtained using data mining. Decision tree models, one of the data mining techniques, and J48 algorithm have been studied in 5 different scenarios.

In addition to these factors, the most important issues in the scenarios were found to be the corporate structure of the company, equity capital, overseas experience of managers, automation usage rates and advertising expenditures, and it was observed that these issues were effective in many scenarios. The determination of these issues was one of the important results obtained from the study.

The other important result and suggestion of our study is decision tree modeling should be conducted by using logistic regression findings of determinants / variables in order to produce more significant results. In case of so many variables, a decision tree may not give successful or clean modeling. Since pre-modeling by logistic regression may eliminate most of the relatively insignificant variables, this logistic regression promoted decision tree approach is recommended for future decision tree studies.

\section{Acknowledgements - Zahvala}

This study conveys the important results of the doctoral thesis study entitled "Analysis of Export Performance Determinants in Furniture Industry: Fuzzy AHP and Decision Tree Modeling" of Alper Aytekin directed by Mehmet Pekkaya.

\section{REFERENCES}

\section{LITERATURA}

1. Aaby, N. E.; Slater, F. S., 1989: Management influences on export performance: A review of the empirical literature 1978 - 1988. International Marketing Review, 6 (4): 7-26. https://doi.org/10.1108/EUM0000000001516.

2. Akyol, A.; Akeshurst, G., 2003: An investigation of export performance variations related to corporate export market orientation. European Business Review, 15 (1): 5-19. https://doi.org/10.1108/09555340310455155.

3. Albaum, G.; Tse, D. K., 2001: Adaptation of international marketing strategy components, competitive advantage and firm performance: A study of Hong Kong Exporters. Journal of International Marketing, 9 (4): 59-81. http://dx.doi.org/10.1509/jimk.9.4.59.19943.

4. Alvarez, R. E., 2002: Determinants of firm export performance in a less developed country. Anderson Graduate School of Management, UCLA, pp. 1-30.

5. Alvarez, R. E., 2004: Sources of export success in small and medium-sized enterprises: The impact of public programs. International Business Review, 13 (3): 383-400. https://doi.org/10.1016/j.ibusrev.2004.01.002.

6. Amine, L. S.; Çavuşgil, S. T., 1986: Export marketing strategies in the British clothing industry. European Journal of Marketing, 20 (7): 21-33. https://doi.org/10.1108/EUM0000000004653.

7. Andersen, B.; Moen, R., 1999: Integrating benchmarking and poor-quality cost measurement for assisting the qual- 
ity management work. Benchmarking: An International Journal, 6 (4): 291-301. https://doi.org/10.1108/14635779910288541.

8. Anderson, A. R.; McAuley, A., 1999: Marketing landscapes: the social context. Qualitative Market Research, 2(3): 176-188. https://doi.org/10.1108/13522759910291680.

9. Axinn, C. N.; Thach, S. V., 1990: Linking export performance to the marketing practices of machine tool exporters. Çavuşgil, S. T.; Axinn, C. (eds.), Advances in International Marketing, JAI Press, pp. 117-139.

10. Aydemir, B., 2017: Veri Madenciliği Yöntemleri Kullanarak Meslek Yüksek Okulu Öğrencilerinin Akademik Başarı Tahmini, Master Thesis. Pamukkale University, Graduate School of Natural and Applied Sciences, Denizli.

11. Balabanis, G. I.; Katsikea, E. S., 2003: Being an entrepreneurial exporter: Does it pay? International Business Review, 12 (2): 233-252.

12. Baldauf, A.; Cravens, D. W.; Wagner, U., 2000: Examining determinants of export performance in small open economies. Journal of World Business, 35 (1): 61-79.

13. Beamish, P. W.; Karavis, L.; Goerzen, A.; Lane, C., 1999: The relationship between organizational structure and export performance. Management International Review, 39 (1): 37-54.

14. Beamish, P. W.; Craig, R.; McLellan, K., 1993: The performance characteristics of Canadian versus UK exporters in small and medium-sized firms. Management International Review, 33 (2): 121-137.

15. Bekteshi, S. A., 2020: Firm size related to export performance. International Journal of Economics \& Business Administration (IJEBA), 0(1): 51-61.

16. Bodur, M., 1994: Foreign market indicators, structural resources and marketing strategies as determinants of export performance. Çavuşgil, S. T.; Axinn, C. (eds.), Advances in International Marketing, JAI Press, Greenwich, pp. 183-205.

17. Brouthers, L. E.; Nakos, G., 2005: The role of systematic international market selection on small firms' export performance. Journal of Small Business Management, 43 (4): 363-381. https://doi.org/10.1111/j.1540-627X.2005.00142.x.

18. Brouthers, L. E.; Xu, K., 2002: Product stereotypes, strategy and performance satisfaction: The case of Chinese exporters. Journal of International Business Studies, 33 (4): 657-677.

19. Cadogan, J. W.; Sundqvist, S.; Salminen, R. T.; Puumalainen, K., 2005: Export marketing, inter functional interactions and performance consequences. Journal of the Academy of Marketing Science, 33 (4): 520-535.

20. Chan, T. S., 1992: Emerging trends in export channel strategy: an investigation of Hong Kong and Singaporean firms. European Journal of Marketing, 26 (3): 18-26.

21. Chen, I. J.; Paulraj, A.; Lado, A. A., 2004: Strategic purchasing, supply management, and firm performance. Journal of Operations Management, 22 (5): 505-523. https://doi.org/10.1016/j.jom.2004.06.002.

22. Chetty, S.; Hamilton, R. T., 1993: Firm-level determinants of export performance: a meta-analysis. International Marketing Review, 10 (3): 26-34. https://doi.org/10.1108/02651339310040643.

23. Chung, H. F. L., 2003: International standardization strategies: The experiences of Australian and New Zealand firms operating in the greater China markets. Journal of International Marketing, 11 (3): 48-82. https://doi.org/10.1509/jimk.11.3.48.20156.
24. Chung, H. F. L., 2012: Export market orientation, managerial ties, and performance. International Marketing Review, 29 (4): 403-423. https://doi.org/10.1108/02651331211242638.

25. Contractor, F. J.; Kundu, S.; Hsu, C. C., 2003: A threestage theory of international expansion: The link between multinationality and performance in the service sector. Journal of International Business Studies, 34 (1): 5-18.

26. Contractor, F. J.; Kumar, V.; Kundu, S., 2007: Nature of the relationship between international expansion and performance: The case of emerging market firms. Journal of World Business, 42 (4): 401-417.

27. Cooper, R. G.; Kleinschmidt, E. J., 1985: The Impact of export strategy on export sales performance. Journal of International Business Studies, 16 (1): 37-55.

28. Coviello, N.; Munro, H., 1997: Network relationships and the internationalisation process of small software firms. International Business Review, 6 (4): 361-386. https://doi.org/10.1016/S0969-5931(97)00010-3.

29. Crick, D.; Jones, M. V., 2000: Small high-technology firms and international high-technology markets. Journal of International Marketing, 8 (2): 63-85. https://doi.org/10.1509/jimk.8.2.63.19623.

30. Czinkota, M. R.; Ursic, M., 1991: Classification of exporting firms according to sales and growth into a share matrix. Journal of Business Research, 22 (3): 243-253. https://doi.org/10.1016/0148-2963(91)90005-I.

31. Czinkota, M. R.; Ronkainen, I. A., 1995: International Marketing, Dryden Press, 815.

32. Çavuşgil, S. T., 1984: Differences among exporting firms based on their degree of internationalization. Journal of Business Research, 12 (2): 195-208. https://doi.org/10.1016/0148-2963(84)90006-7.

33. Çavuşgil, S. T.; Zou, S., 1994: Marketing strategy-performance relationships: An investigation of the empirical link in export market ventures. Journal of Marketing, 58 (1): $1-21$.

34. Çavuşgil, S. T.; Zou, S.; Naidu, G. M., 1993: Product and promotion adaptation in export ventures: An empirical investigation. Journal of International Business Studies, 24 (3): 479-506.

35. Çulpan, R., 1989: Export behaviour of firms: Relevance of firm size. Journal of Business Research, 18 (3): 207 218. https://doi.org/10.1016/0148-2963(89)90045-3.

36. Dean, D. L.; Mengüç, B.; Myers, C. P., 2000: Revisiting firm characteristics, strategy and export performance relationship: A survey of the literature and an investigation of New Zealand small manufacturing firms. Industrial Marketing Management, 29 (5): 461-477. https://doi.org/10.1016/S0019-8501(99)00085-1.

37. Deng, W.; Tsao, S. W.; Lucas, J. N.; Leung, C. S.; Cheung, A. L. M., 2002: A new method for improving metaphase chromosome spreading. Cytometry, 51A (1): 46-51. https://doi.org/10.1002/cyto.a.10004.

38. Dhanaraj, C.; Beamish, P. W., 2003: A resource-based approach to the study of export performance. Journal of Small Business Management, 41 (3): 242-261. https://doi.org/10.1111/1540-627X.00080.

39. Dichtl, E.; Koeglmayr, H. G.; Mueller, S., 1990: International orientation as a precondition for export success. Journal of International Business Studies, 21 (1): 23-40.

40. Dominguez, L. V.; Sequeira, C. G., 1993: Determinants of LDC exporters' performance: A cross-national study. Journal of International Business Studies, 24 (1): 19-40.

41. Francis, J.; Collins-Dodd, C., 2004: Impact of export promotion programs on firm competencies, strategies and performance - The case of Canadian high-tech SMEs. International Marketing Review, 21 (4): 474-495. 
42. Fraser, C.; Hite, R. E., 1990: Impact of international marketing strategies on performance in diverse global markets. Journal of Business Research, 20 (3): 249-262. https://doi.org/10.1016/0148-2963(90)90016-7.

43. Gemunden, H. G., 1991: Success factors of export marketing: A meta-analytic critique of the empirical studies, New perspectives on international marketing. Paliwoda, S. J. (ed.), Routledge, London.

44. Gençtürk, E. F.; Kotabe, M., 2001: The effect of export assistance program usage on export performance: a contingency explanation. Journal of International Marketing, 9 (2): 51-72.

45. Grant, R. M., 1996: Toward a knowledge-based theory of the firm. Strategic Management Journal, 17: 109-122. https://doi.org/10.1509/jimk.9.2.51.19886.

46. Griffith, D. A.; Dimitrova, B. V., 2014: Business and cultural aspects of psychic distance and complementarity of capabilities in export relationships. Journal of International Marketing, 22 (3): 50-67.

https://doi.org/10.1509/jim.14.0019.

47. Gümüşçü, A.; Taşaltın, R.; Aydilek, İ. B., 2016: C4.5 Karar ağaçlarında genetik algoritma ile budama. Dicle University, DUFED, 5 (2): 77-80.

48. Haahti, A.; Madupu, V.; Yavaş, U.; Babakus, E., 2005: Cooperative strategy, knowledge intensity and export performance of small and medium sized enterprises. Journal of World Business, 40 (2): 124-138.

49. Hart, S.; Tzokas, N., 1999: The impact of marketing research activity on SME export performance: Evidence from the UK. Journal of Small Business Management, 37 (2): 63-76.

50. Hoang, B. P., 1998: A causal study of relationships between firm characteristics, international marketing strategies, and export performance. Management of International Review, 38: 73-93.

51. Holzmüller, H. H.; Stottinger, B., 1996: Structural modeling of success factors in exporting: cross-validation and further development of an export performance model. Journal of International Marketing, 4 (2): 29-55.

52. Ibeh, K., 2003: On the internal drivers of export performance among Nigerian firms: empirical findings and implications. Management Decision, 41 (3): 217-225. https://doi.org/10.1108/00251740310469404.

53. Ibeh, K.; Wheeler, C. N., 2005: A resource-centered interpretation of export performance. International Entrepreneurship and Management Journal, 1 (4): 539-556.

54. Ibeh, K.; Young, S., 2001: Exporting as an entrepreneurial act: An empirical study of Nigerian firms. European Journal of Marketing, 35 (5/6): 566-586.

55. Imran, M.; Saleem, H. M. N.; Iqbal, J.; Rafi, S. M. T., 2020: Entrepreneurial orientation and firm's export performance: Evidence from surgical industry. Journal of Management Sciences, 7 (1): 47-63. https://doi.org/10.20547/jms.2014.2007104.

56. Ito, K.; Pucik, V., 1993: R\&D spending, domestic competition and export performance of Japanese manufacturing firms. Strategic Management Journal, 14 (1): 61-75. https://doi.org/10.1002/smj.4250140107.

57. Jones, M. V., 2001: First steps in internationalization: concepts and evidence from a sample of small high-technology firms. Journal of International Management, 7 (3): 191-210. https://doi.org/10.1016/S1075-4253(01)00044-8.

58. Julien, P. A.; Ramangalahy, C., 2008: Competitive strategy and performance of exporting SMEs: An empirical investigation of the impact of their export information search and competencies. Entrepreneurship Theory and Practice, 27 (3): 227-245.

https://doi.org/10.1111/1540-8520.t01-1-00002.
59. Katsikeas, C.; Piercy, N.; Ioannidis, C., 1996: Determinants of export performance in a European context. European Journal of Marketing, 30 (6): 6-35. https://doi.org/10.1108/03090569610121656.

60. Katsikeas, C. S.; Samiee, S.; Theodosiou, M., 2006: Strategy fit and performance consequences of international marketing standardization. Strategic Management Journal, 27 (9): 867-890. https://doi.org/10.1002/smj.549.

61. Kavzaoğlu, T.; Çölkesen, İ., 2010: Karar Ağaçları İle Uydu Görüntülerinin Sınıflandırılması: Kocaeli Örneği. Harita Teknolojileri Elektronik Dergisi, 2 (1): 36-45.

62. Kaynak, E.; Wellington, K. K., 1993: Environment, strategy, structure and performance in the context of export activity: an empirical study of Taiwanese manufacturing firms. Journal of Business Research, 27 (1): 33-49. https://doi.org/10.1016/0148-2963(93)90014-G.

63. Kogut, B.; Zander, U., 1992: Knowledge of the firm, combinative capabilities and the replication of technology. Organization Science, 3 (3): 383-397. https://doi.org/10.1287/orsc.3.3.383.

64. Lages, L. F.; Montgomery, D. B., 2004: Export performance as an antecedent of export commitment and marketing strategy adaptation: Evidence from small and medium sized exporters. European Journal of Marketing, 38 (9/10): 1186-1214.

65. Langloisa, R.; Frank, J., 2011: A clarification of the terms used in comparing semi-automated particle selection algorithms in Cryo-EM. Journal of Structural Biology, 175 (3): 348-352. https://doi.org/10.1016/j.jsb.2011.03.009.

66. Landis, R. J.; Koch, G. G., 1977: The measurement of observer agreement for categorical data. Biometrics, 33 (1): 159-174.

67. Lee, C.; Griffith, D. A., 2004: The marketing strategy performance relationship in an export driven developing economy: A Korean illustration. International Marketing Review, 21 (3): 321-334. https://doi.org/10.1108/02651330410539648.

68. Lejpras, A., 2019: Determinants of export performance: differences between service and manufacturing SMEs. Service Business, 13: 171-198. https://doi.org/10.1007/s11628-018-0376-7.

69. Li, L., 2004: An examination of the foreign market knowledge of exporting firms based in the People's Republic of China: its determinants and effect on export intensity. Industrial Marketing Management, 33 (7): 561-572. https://doi.org/10.1016/j.indmarman.2004.01.001.

70. Li, L.; Ogunmokun, G. O., 2001: The influence of interfirm relational capabilities on export advantage and performance: an empirical analysis. International Business Review, 10 (4): 399-420. https://doi.org/10.1016/S0969-5931(01)00023-3.

71. Lim, J. S.; Sharkey, T. W.; Kim, K. I., 1996: Competitive environmental scanning and export involvement: an initial inquiry. International Marketing Review, 13 (1): 65 80. https://doi.org/10.1108/02651339610111353.

72. Lopez-Rodriguez, J.; Rodriguez, R. M. G., 2005: Technology and export behavior: A resource-based view approach. International Business Review, 14 (5): 539-557.

73. Louter, P. J.; Ouwerkerk, C.; Bakker, B. A., 1991: An inquiry into successful exporting. European Journal of Marketing, 25(6): 7-23. https://doi.org/10.1108/03090569110001429.

74. Madsen, T. K., 1989: Successful export marketing management: some empirical evidence. International Marketing Review, 6 (44): 41-57. https://doi.org/10.1108/EUM0000000001518.

75. Manzanares, F. V., 2019: Export performance of SMEs: An empirical analysis of the mediating role of corporate 
image. Journal of Small Business Management, 57 (2): 386-399. https://doi.org/10.1111/jsbm.12337.

76. Morgan, N. A.; Zou, S.; Vorhies, D.; Katsikeas, C. S., 2003: Experiential and informational knowledge, architectural marketing capabilities and the adaptive performance of export ventures: A cross-national study. Decision Sciences, 34 (2): 287-319. https://doi.org/10.1111/1540-5915.02375.

77. Morgan, N. A.; Kaleka, A.; Kastikeas, C. S., 2004: Antecedents of export venture performance: A theoretical model and empirical assessment. Journal of Marketing, 68: 90-108. https://doi.org/10.1509/jmkg.68.1.90.24028.

78. Myers, M. B., 1999: Incidents of gray market activity among US exporters: Occurrences, characteristics, and consequences. Journal of International Business Studies, 30 (1): 105-126.

79. O'Cass, A.; Julian, C., 2003: Examining firm and environmental influences on export marketing mix strategy and export performance of Australian exporters. European Journal of Marketing, 37 (3/4): 366-384. https://doi.org/10.1108/03090560310459005.

80. Oviatt, B. M.; McDougall, P. P., 1994: Toward a theory of international new ventures. Journal of International Business Studies, 25 (1): 45-64.

81. Patterson, P. G.; Cicic, M.; Shoham, A., 1997: A temporal sequence model of satisfaction and export intentions of service firms. Journal of Global Marketing, 10 (4): 23-43.

82. Piercy, N. F.; Kaleka, A.; Katsikeas, C. S., 1998: Sources of competitive advantage in high performing exporting companies. Journal of World Business, 33 (4): 378-393. https://doi.org/10.1016/S1090-9516(99)80081-9.

83. Prasad, V. K.; Ramamurthy, K.; Naidu, G. M., 2001: The influence of internet-marketing integration on marketing competencies and export performance. Journal of International Marketing, 9 (4): 82-110. https://doi.org/10.1509/jimk.9.4.82.19944.

84. Quinlan, J. R., 1999: Simplifying decision trees. International Journal of Man-Machine Studies, 51 (2): 497-510. https://doi.org/10.1016/S0020-7373(87)80053-6.

85. Raven, P. V.; McCullough, J. M.; Tansuhaj, P. S., 1994: Environmental influences and decision-making uncertainty in export channels: effects on satisfaction and performance. Journal of International Marketing, 2 (3): 37 59. https://doi.org/10.1177/1069031X9400200303.

86. Reid, S., 1983: Firm internationalization, transaction costs and strategic choice. International Marketing Review, 1 (2): 44-56. https://doi.org/10.1108/eb008251.

87. Richey, R. G.; Myers, M. B., 2001: An investigation of market information use in export channel decisions. International Journal of Physical Distribution \& Logistics Management, 31 (5): 334-353. https://doi.org/10.1108/09600030110395157.

88. Robertson, C.; Chetty, S. K., 2000: A contingency-based approach to understanding export performance. International Business Review, 9 (2): 211-235. https://doi.org/10.1016/S0969-5931(99)00037-2.

89. Rocha, A. D.; Christensen, C. H.; Cunha, D.; Eduardo, C., 1990: Aggressive and passive exporters: A study in the Brazilian furniture industry. International Marketing Review, 7 (5): 6-16. https://doi.org/10.1108/EUM0000000001531.

90. Roper, S.; Love, J. H., 2002: Innovation and export performance: Evidence from UK and German Manufacturing Plants. Research Policy, 31 (7): 1087-1102. https://doi.org/10.1016/S0048-7333(01)00175-5.
91. Rose, G. M.; Shoham, A., 2002: Export performance and market orientation: establishing an empirical link. Journal of Business Research, 55 (3): 217-225. https://doi.org/10.1016/S0148-2963(00)00139-9.

92. Roth, S. M., 1995: The Effects of culture and socioeconomics on the performance of global brand image strategies. Journal of Marketing Research, 32 (2): 163-175. https://doi.org/10.1177/002224379503200204.

93. Samiee, S.; Anckar, P., 1998: Currency choice in industrial pricing: A cross-national evaluation. Journal of Marketing, 62 (3): 112-127. https://doi.org/10.1177/002224299806200308.

94. Schlegelmilch, B. B.; Ross, A. G., 1987: The influence of managerial characteristics on different measures of export success. Journal of Marketing Management, 3 (2): 145-158.

95. Seifert, B.; Ford, J., 1989: Are exporting firms modifying their product, pricing and promotion policies? International Marketing Review, 6 (6): 53-68.

96. Shoham, A., 1999a: Bounded rationality, planning, standardization of international strategy and export performance: A structural model. Journal of International Marketing, 7 (2): 24-50.

https://doi.org/10.1177/1069031X9900700203.

97. Shoham, A., 1999b: Export performance: A conceptualization and empirical assessment, Journal of International Marketing, 6 (3): 59-81. https://doi.org/10.1177/1069031X9800600308.

98. Shoham, A.; Evangelista, F.; Albaum, G., 2002: Strategic firm type and export performance. International Marketing Review, 19 (3): 236-258. https://doi.org/10.1108/02651330210430686.

99. Singer, T. O.; Czinkota, M. R., 1994: Factors associated with effective use of export assistance. Journal of International Marketing, 2 (1): 53-71. https://doi.org/10.1177/1069031X9400200104.

100. Solberg, C. A., 2002: The perennial issue of adaptation or standardization of international marketing communication: organizational contingencies and performance. Journal of International Marketing, 10 (3): 1-21. https://doi.org/10.1509/jimk.10.3.1.19546.

101. Stewart, D. B.; McAuley, A., 2000: Congruence of domestic and export marketing strategies: An empirical investigation of its performance implications. International Marketing Review, 17 (6): 563-586. https://doi.org/10.1108/02651330010356627.

102. Stöttinger, B.; Holzmüller, H. H., 2001: Cross national stability of an export performance model: A comparative study of Austria and the US. Management International Review, 41 (1): 7-28.

103. Styles, C.; Ambler, T., 1994: Successful export practice: The UK experience. International Marketing Review, 11 (6): 23-47. https://doi.org/10.1108/02651339410072999.

104. Styles, C.; Ambler, T., 2000: The impact of relational variables on export performance: an empirical investigation in Australia and the UK. Australian Journal of Management, 25 (3): 261-281. https://doi.org/10.1177/031289620002500302.

105. Styles, C.; Patterson, P. G.; Farid, A., 2008: A relational model of export performance. Journal of International Business Studies, 39 (5): 880-900.

106. Şık, M. Ş., 2014: Veri Madenciliği ve Kanser Erken Teşhisinde Kullanımı, Master Thesis, İnönü University, Malatya.

107. Teece, D.; Pisano, G.; Shuen, A., 1997: Dynamic capabilities and strategic management. Strategic Management Journal, 18 (7): 509-533. https://doi.org/10.1002/ 
(SICI) 1097-0266(199708)18:7<509::AIDSMJ882>3.0.CO;2-Z.

108. Thirkell, P. C.; Dau, R., 1998: Export performance: success determinants for New Zealand manufacturing exporters. European Journal of Marketing, 32 (9/10): 813829. https://doi.org/10.1108/03090569810232273.

109. Wakelin, K., 1998: Innovation and export behavior at the firm level. Research Policy, 26 (7/8): 829-841. https://doi.org/10.1016/S0048-7333(97)00051-6.

110. Walters, P. G.; Samiee, S., 1990: A model for assessing performance in small US exporting firms. Entrepreneurship Theory and Practice, 15 (2): 33-50. https://doi.org/10.1177/104225879101500205.

111. Walters, P. G. 1993: Patterns of formal planning and performance in US exporting firms. Management International Review, 33 (1): 43-63.

112. White, D. S.; Griffith, D. A.; Ryans, J. K., 1998: Measuring export performance in service industries. International Marketing Review, 15 (3): 188-204. https://doi.org/10.1108/02651339810221106.

113. Wolff, J. A.; Pett, T., 2000: Internationalization of small firms: An examination of export competitive patterns, firm size and export performance. Journal of Small Business Management, 38 (2): 34-47.

114. Yeoh, P. L., 2004: International learning: antecedents and performance implications among newly internationalizing companies in an exporting context. International Marketing Review, 21 (4/5): 511-535. https://doi.org/10.1108/02651330410547171.
115. Zou, S.; Stan, S., 1998: The determinants of export performance: A review of the empirical literature between 1987 and 1997. International Marketing Review, 15 (5): 333-356.

https://doi.org/10.1108/02651339810236290.

116. ***Anadolu Agency, 2017: "IMF Türkiye'nin büyüme beklentisini yükseltti", https://www.ntv.com.tr/ekonomi/ imf-turkiyenin-buyume-beklentisini-yukseltti,YZpv FV7ipU-IxAsEX3_b0w (Accessed Nov. 27, 2017).

117. ***TRADEMAP, 2019: List of exporters for the selected products 9401-9404, Export-import international trade in goods statistics by product group, International trade center, Trade statistics, http://www.trademap.org (Accessed Jul, 5, 2019).

\section{Corresponding address:}

Assoc. Prof. ALPER AYTEKIN, PhD.

\section{Bartin University}

Faculty of Economics and Administrative Sciences Department of Management Information Systems Bartin, TURKEY

e-mail: aytekin@bartin.edu.tr 